\title{
The use of management accoun- ting systems in functionally differentiated organizations
}

Prof. Dr. R.I. van Hoek

Bouwens, Jan, The use of management accoumting systems in functionally differentiated organizations. Thesis, Center for Economic Research, Tilburg University, 1998

Het proefschrift van Jan Bouwens verdient krediet vanwege de (managerial) relevantie. Verschillende Harvard Business Review publicaties (Pine, 1993 en Gilmore \& Pine, 1997) en zelfs Mintzberg (Lampel \& Mintzberg, 1996) wijzen op het toenemende belang van klantspecificatie in een tijdperk van steeds meer eisende klanten en marktomstandigheden met onder meer verkortende productlevenscycli, toenemende productdifferentiatie en verkortende levertijden als symptomen. De kern van de bijdrage van Bouwens bestaat eruit dat wordt nagegaan hoe de toepassing van customization de inrichting van management accounting systemen beïnvloedt.

Op basis van een studie onder 85 ondernemingen in Nederland stelt Bouwens vast dat de toepassing van customization tot een grotere onderlinge afhankelijkheid van functionele afdelingen leidt. Dit wijst op het belang van een cross-functionele benadering voor customization.

Verder bestaan er directe relaties tussen de toepassing van customization en de scope van management accounting systemen (hierna: MAS). Dit wijst op het belang van:

- een omvattende MAS (in termen van interne en externe focus, financiële en niet-financiële maatstaven en ex post en ex ante maatstaven);

Prof. Dr. R.I. van Hoek is verbonden aan de Universiteit Gent, België en de Erasmus Universiteit te Rotterdam.
- aggregatie van informatie (naar functionele afdelingen, tijdvakken en in verschillende beslissingsondersteunende calculaties/modellen); en

tijdigheid van informatie (frequentie en snelheid van informatievoorziening) voor productieafdelingen.

Daamaast bestaat er via onderlinge afhankelijkheid een indirecte relatie tussen customization en MAS met de aggregatie en tijdigheid van informatie en de integratie van informatie (niet alleen specifieke targets voor afzonderlijke activiteiten en organisatorische eenheden maar ook informatie over interactie tussen organisatorische eenheden).

Daarmee wordt aangegeven dat het nastreven van customization niet alleen hogere eisen stelt aan de integratie van organisaties over functionele en afdelingsgrenzen heen, maar dat (daarmee) en met het directer inspelen op klanten de behoefte aan snelle, omvattende, geaggregeerde en geïntegreerde informatie toeneemt. Daarmee krijgen de controller en de accountingafdeling, naast ICT-systemen natuurlijk, een voorname rol in de moderne strategie van customization.

Kredietwaardig is niet alleen de onderwerpkeuze van Bouwens, maar ook de aanpak van de datacollectie. Binnen de 85 ondernemingen zijn drie tot vier managers in de studie betrokken. Deze arbeidsintensieve metingen maken het mogelijk perceptieverschillen tussen productie en verkoopafdeling, algemeen management en controllers waar te nemen. Impliciet is het daarmee voor een deel zelfs mogelijk om de functie van de controller te indiceren op basis van 
zijn positie in, en perceptie van, informatievoorziening. Met de meting wordt het cross-functionele element recht gedaan (het interorganisatorische aspect blijft daarmee nog wel buiten beschouwing). Wat dat betreft had de meting van customization zich kunnen uitstrekken tot de rol van de verschillende functies in het bewerkstelligen van klantspecificatie (volledige of partiële klantspecificatie (mass customization), zoals het theoretisch raamwerk wel suggereert). En wellicht zelfs tot de rol van specifieke activiteiten in customization. Dit omdat een focus op operationele beslissingen met betrekking tot customization wordt gehanteerd. In eerder onderzoek van mijn kant (Van Hoek, 1998) bleken dit relevante aspecten. Behoudens een aantal kleine foutjes (zoals de grafische weergave van het onderzoeksmodel waarin hypothesen 2 en 3 zijn omgewisseld), blijft de bijdrage verder staan. Wel is het de vraag of de survey-methode, hoewel accuraat toegepast, op zich de beste is. Er is over mass customization in het algemeen nog weinig materiaal beschikbaar, laat staan in de context van management accounting. Terwijl we dus al proberen te generaliseren over relaties tussen constructen, zijn we er nog niet zeker van of we de juiste constructen gebruiken. Ergo, de fase van kwalitatief onderzoek gericht op het achterhalen van relevante factoren en analytische verbanden is nog niet afgerond.

Bouwens doet nog een aantal aanbevelingen voor vervolgonderzoek die zich met name richten op verbetering van de gebruikte items en metingen naast een verdieping en verbreding van de studie naar de aspecten van MAS. Wellicht dat ik het mij hier, mede in het kader van voorgaande opmerking, mag permitteren twee additionele suggesties te doen. Ten eerste is het wellicht zinnig de veronderstelde relaties precies anders- om te onderzoeken. Het draait dan niet meer om de vraag in hoeverre de toepassing van customization een impact heeft op of eisen stelt aan MAS, maar in hoeverre management accounting de implementatie van customization mogelijk maakt (een drijver is). Daarnaast is het wellicht zinvol om behalve naar de inrichting van MAS ook naar de inhoud van metingen en de gebruikte maatstaven te kijken; niet alleen het 'hoe' maar ook het 'waarom' en 'wat' van MAS. Dit omdat een groot gedeelte van de gemeten items nu het soort informatiebehoefte weergeeft. ICT-specialisten zouden kunnen zeggen dat systemen in de sfeer van bijvoorbeeld ERP kunnen voorzien in omvattende, directe en continu beschikbare, geïntegreerde en geaggregeerde informatie, onafhankelijk van management accountants. Deze systemen zijn echter niet in staat om bijvoorbeeld de benodigde prestatie-indicatoren en prestatienormen te selecteren en te definiëren om met customization daadwerkelijk 'de markt op zijn kop te zetten'. Dit nu lijkt mij een academische, praktisch relevante uitdaging die nog staat en alwaar we misschien eerst maar eens kwalitatief onderzoek moeten inzetten.

\section{I T E R A T U U R}

Gilmore, J.H. en B.J. Pine, (1997), The four faces of mass customization, Harvard Business Review, jrg. 75, januari/ februari, pp. 91-101.

Hoek, R.I. van, (1998), Postponed manufacturing in European supply chains, a triangular approach, Utrecht: KNAG.

Lampel, J. en H. Mintzberg, (1996), Customizing customization, Sloan Management Review, najaar, pp. 21-30.

Pine II, J.P. Mass customization, Boston: Harvard Business School Press, 1993. 